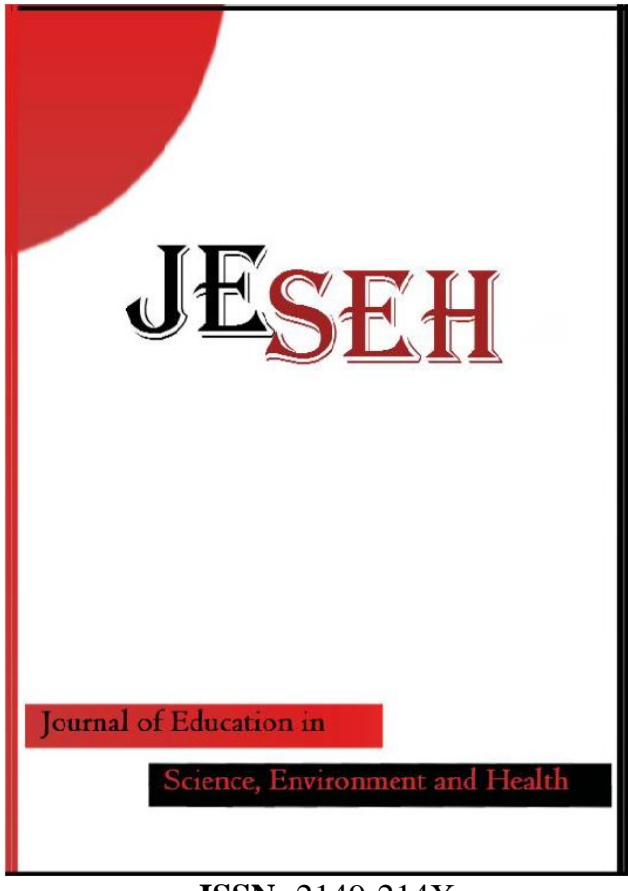

ISSN: $2149-214 \mathrm{X}$
Journal of Education in Science, Environment and Health

www.jeseh.net

Resources used by Lebanese Secondary Physics Teachers' for Teaching Electricity: Types, Objectives and Factors Affecting their Selection

Bassel Chazbeck ${ }^{1}$, Zalpha Ayoubi ${ }^{2}$

Lebanese University

To cite this article:

Chazbeck, B. \& Ayoubi, Z. (2018). Resources used by Lebanese secondary physics teachers' for teaching electricity: Types, objectives and factors affecting their selection. Journal of Education in Science, Environment and Health (JESEH), 4(2), 118-128. DOI: $10.21891 /$ jeseh.409487

This article may be used for research, teaching, and private study purposes.

Any substantial or systematic reproduction, redistribution, reselling, loan, sub-licensing, systematic supply, or distribution in any form to anyone is expressly forbidden.

Authors alone are responsible for the contents of their articles. The journal owns the copyright of the articles.

The publisher shall not be liable for any loss, actions, claims, proceedings, demand, or costs or damages whatsoever or howsoever caused arising directly or indirectly in connection with or arising out of the use of the research material. 


\title{
Resources Used by Lebanese Secondary Physics Teachers' for Teaching Electricity: Types, Objectives and Factors Affecting their Selection
}

\author{
Bassel Chazbeck, Zalpha Ayoubi
}

\begin{tabular}{|c|c|}
\hline Article Info & Abstract \\
\hline History & \multirow{9}{*}{$\begin{array}{l}\text { The purpose of this research was to study the system of resources, the objectives } \\
\text { of their use and the factors that affect the selection and integration of the } \\
\text { different resources by Lebanese secondary physics teachers in their teaching in } \\
\text { general and for teaching Electricity in particular. For this aim, a qualitative } \\
\text { approach was used and the research was designed as a collective case study } \\
\text { where four teachers were purposefully selected. Interviews and classroom } \\
\text { observations were the main data collection tools. Results showed that teachers } \\
\text { used different types of resources: Paper resources, audio-visual resources, object } \\
\text { resources, and evoked resources to elaborate their teaching activities. They paid } \\
\text { a particular attention to the experimental activity using object and audio-visual } \\
\text { resources to enhance students' comprehension of Physics concepts. Moreover } \\
\text { teachers referred to the virtual laboratory to be more efficient than the real lab at } \\
\text { the level of precision, clarity and management, in addition to its importance for } \\
\text { illustration at the microscopic scale. Results also revealed that the school setting, } \\
\text { time constraints and teachers' professional knowledge are the main factors that } \\
\text { affect the selection and the integration of resources. }\end{array}$} \\
\hline $\begin{array}{l}\text { Received: } \\
\text { 27 June } 2017\end{array}$ & \\
\hline $\begin{array}{l}\text { Accepted: } \\
\text { 07 January }\end{array}$ & \\
\hline Keywords & \\
\hline Physics teaching & \\
\hline Teaching electricity & \\
\hline Resources & \\
\hline $\begin{array}{l}\text { School setting } \\
\text { Teachers' professional }\end{array}$ & \\
\hline & \\
\hline
\end{tabular}

\section{Introduction}

Teaching is a complex activity where teachers are obliged to present specific content with a specific approach in order to facilitate the learning process and enhance students' understanding. (Shulman, 1987) Learning and teaching processes are affected by many factors some of which are related to the teacher qualifications and personality, while others are related to the content taught and students' capacities. Teaching science encounters more obstacles than other teachers since most of the scientific concepts are abstract and difficult for students to learn. Moreover, secondary physics teachers may face other difficulties such as the lack of school equipment and materials, as well as, the lack of initial and continuous teachers' training courses in general and those concerning new technologies in particular (i.e., Interactive White Board , educational software, etc.). Lack of material can have a direct influence on teaching of science since the experimental activities usually require a well-equipped laboratory especially when teaching quantitative physics. Even computer rooms become a necessity to install software and to project instructional videos in order to integrate the Information and Communication Technologies (ICTs) in education. All of these constraints form gaps for teachers' professional work in preparing and teaching scientific content. To fill these gaps, teachers are left with the obligation to search for teaching resources that enable them to produce new documents of teaching for later use in their classrooms. These resources should be well selected, adapted and transformed to be integrated within the content taught in class (Gueudet and Trouche, 2008).

In the last decades, the progression of technology and the proliferation of the usage of internet led to the creation of a wide range of online resources in the domain of education. In addition to the traditional resources (curriculum material and books), these resources come to stand as additional support for teachers in their profession. Those resources include digital textbooks, websites, software, online exercises, online courses, audios, videos, photos and simulations. The resources can help teachers prepare and present the content to be taught, thus leading to a change in their professional work (Sabra, 2011). Moreover, the resources can help teachers in approaching difficult concepts to their students (Flick \& Bell, 2000). Due to the abundance and the diversity of resources, science teachers should make their selection among a large number of resources varying between traditional, (books, textbooks, scientific magazines, encyclopedia, etc...), digital and online resources (texts, websites, simulations, videos, etc...). 
In the twenty first century, technology becomes an essential factor in the progression of many domains in the human jobs. In education, technology and digital resources played an essential role in the field of pedagogy such as teaching and learning process (Spring, 2011). Despite of the presence of many technological tools and many educational digital resources (in the private schools in particular), their use in the classroom remained not well developed (Jacobsen, 2001). The investigation about the reasons behind the lack of effective technology integration forms the purpose of an empirical science education study conducted by Zgheib (2013). Zgheib showed that the availability of technologies and the proliferation of its use is not sufficient for the development of teachers' use of technology, however, a major shift should occur at the leadership level. To shift teacher's attitudes towards an effective use of educational technology, an organizational support of technology should be integrated through professional development in the whole school culture (Zgheib, 2013).

According to Boujaoude and Abd-El-Khalick (2004) and Boujaoude and El Hage (2009), who analyzed 116 empirical science education studies conducted in Lebanon between the years 1992 and 2008, only three studies conducted in Lebanon were about resources in general and using technology in particular. Shihab (2000) investigated the effect of using web-based hypermedia as an alternative to textbooks on student achievement in a unit about the classification of animals. In 2007 and 2008, two studies were published in the category of technology-aided instruction. The first one is about the mathematization in physics laboratories that incorporated inquiry-enhancing technologies (Jurdak, BouJaoude, \& Ghumrawi, 2007) and the second one investigated the views of both students and teachers of the advantages and limitations of using Information and Communication T0echnology (Eid, 2008). Hammoud (2012) studied the professional work of Chemistry teachers on the resources they realize in order to perform their teaching, particularly with respect to InquiryBased Science Teaching. Shaaban studied the interaction between resources, particularly digital resources, and Biology teachers' conceptions during their teaching preparation and teaching practices of Genetics determinism. She showed that teachers referred to different types of resources to update their scientific knowledge and to enhance student's understanding of some difficult topics like Genetics (Shaaban, 2014).

The professional activities of teachers and the interaction with colleagues affect teachers' practices and their development (Grangeat \& Gray, 2007). Moreover, the implementation of ICT in teaching sciences presents new affordances for science education. In fact, using computer simulations allows teachers and students to explore phenomena that cannot be done experimentally (Webb, 2008). For example, in teaching Physics and with the help of simulation and computers' software, students are able to explore some phenomena that cannot be experienced in the laboratory such as nuclear reactions at microscopic scale or the observation of astronomy at large scale. Thus, technology becomes more relevant for science education.

Therefore, to prepare their teaching activities, teachers should select the convenient resource that they think is important in the teaching process and enhances students' understanding of a specific content. Therefore, the variety of the available resources and the proliferation of technology and digital resources provided physics teachers with a new important category of educational aids. These resources in addition to the traditional ones form a wide range of resources, from which physics teachers selected an adaptable resource to present specific physics content. Since, the unit of Electricity is found in almost all intermediate and secondary classes, this unit is seen as one of the important units in physics. In this study, the researchers aimed to explore teachers' resources, the objectives of their use and the factors affecting the selection and the integration of these resources in teaching preparation and practice in general and in teaching Electricity to grade ten students in particular. For this purpose, the researchers in this study intended to answer the following questions:

1. What are the different resources used by the Lebanese Secondary Physics Teachers in their teaching preparation/ teaching practices in general and in teaching Electricity for grade ten students' in particular?

2. What is the objective of the experimental activity (real and virtual) in teaching Physics in general, and what are the factors that affect the selection and the use of different resources in teaching preparation/ teaching practices of Secondary Physics Teachers?

\section{Theoretical Background}

This study attempts to explore the system of pedagogical "Resources" that secondary physics teachers selected and integrated in their professional work and to investigate the objectives of their use and the factors that affect the selection of these resources. 
The common meaning in education of "resource" refers to material resources. With time and due to the progression of technology and the development of the educational aids, the term resource covered many domains and different meanings. Adler (2010) conceptualized the term "resource" as both a noun and a verb. As a verb "re-source" means to source again or differently where source presents the origin or the place from where a thing comes. She has offered a broad conceptualization of resources that exceeds the material resources and distinguished between several categories of resources: material resources (such as technological tools: table, overhead projector ..., real objects, books, documents, software etc.), human resources (professional and subject knowledge of teachers), social and cultural resources (language) and time.

Based on the proposition of Adler (2010), Gueudet and Trouche (2010) defined the word "resource" as what is likely to re-source the work of teachers. In their work, they distinguished between these resources based on their characteristics: some are "material" (such as manuals, files, real objects etc.) and others are "non-material" (such as interactions with colleagues, students, communities etc.).

During their professional activity, physics teachers develop their teaching content based on various resources. Therefore, they could use bookish resources (textbooks and programs, documents, encyclopedia etc.), educational software and online resources (Artigue \& Gueudet, 2008) or the real objects (physical objects or everyday life objects) which still form the main resource that promotes the work of experimental science teachers. Furthermore, Gueudet and Trouche (2009) found that the collective work plays an important role in the documentation system of teachers. It is based on direct communication between people (teacher-teacher, teacher-student, teacher and others ...). This type of communication which takes place in the educational meetings inside the institutions, associations, networks and society, leads to a new proposition to define a document as "a contract between men " (Pédauque 2006, p.13; as cited by Gueudet \& Trouche, 2009).Physics teachers may also use examples of physics applications from students' everyday life during their practice. Thus, in order to elaborate a comprehensive activity and enhance learning process, physics teachers should make a selection from a wide range of available resources. These resources are presented either concretely in class by a material support or presented by a non-material support. Based on Gueudet and Trouche (2010) this study has adopted the definition of the term resource and distinguished between material and non-material resources:

- The material resources (MR) include the resources used by physics teachers that are present in their work environment. We categorize this type of resources according to the nature of the appropriate materials carrying (bearing) them, and we distinguish between three categories of material resources: the objects resources (OR) that consist of physics and real life objects, audio-visual resources (AVR), that correspond to videos, DVDs, CDs, Photos, simulations, software, etc. finally the paper resources (PR), refer to books, extra sheets, documents, magazines, etc.

- The non-material resources (NMR) or what Adler (2010) called knowledge resources or human resources cover the verbal discourses indicating applications of physics concepts in the real life like the principles of functioning of some machines, natural phenomena etc. Another example concerning Electricity, physics teacher may evoke the functioning of the electric heater or the iron in order to explain the principle of conversion of energy in a resistor. These resources are evoked in class without being presented concretely. Therefore, the teacher could illustrate the principle of conversion of electric energy into other forms of energy by using non-material resources that are called "Evoked Resources" in this study.

In their professional activity, physics teachers may interact with a wide range of resources; these interactions and their consequences hold a central place in teachers' professional development. This work according to Gueudet \& Trouche (2009) is called documentary work, which is the work of the teacher on different resources and what it produces to form the subject or the document of his teaching. According to Gueudet and Trouche (2010), the document prepared by the teacher does not live isolated; it develops over time because of interactions with resources and with other documents. The process of evolution of the documentary system develops over time new documents that can play the role of new resources. In this sense, a resource produced in the classroom is not a document, with time and after revision and modification, it may result in a document. Since this study focused on the teaching of physics, therefore, its particular interest goes to the resources that physics teachers use to teach specific content in the field of physics. In this study secondary Physics teachers' use of resources is studied during their teaching Electricity part in grade ten.

According to Gueudet \& trouche (2008) studying a system of resources or a document requires taking into consideration three intertwined components:

- The material component: Corresponds to the type of the used resources. 
- The physics content component: Involves physics notions, tasks and techniques.

- The didactical component: Corresponds to the organizational elements ranging from mapping over the whole year to planning a session.

Concerning the first component the type of the resources is studied based on the categorization of the material and non material resources.

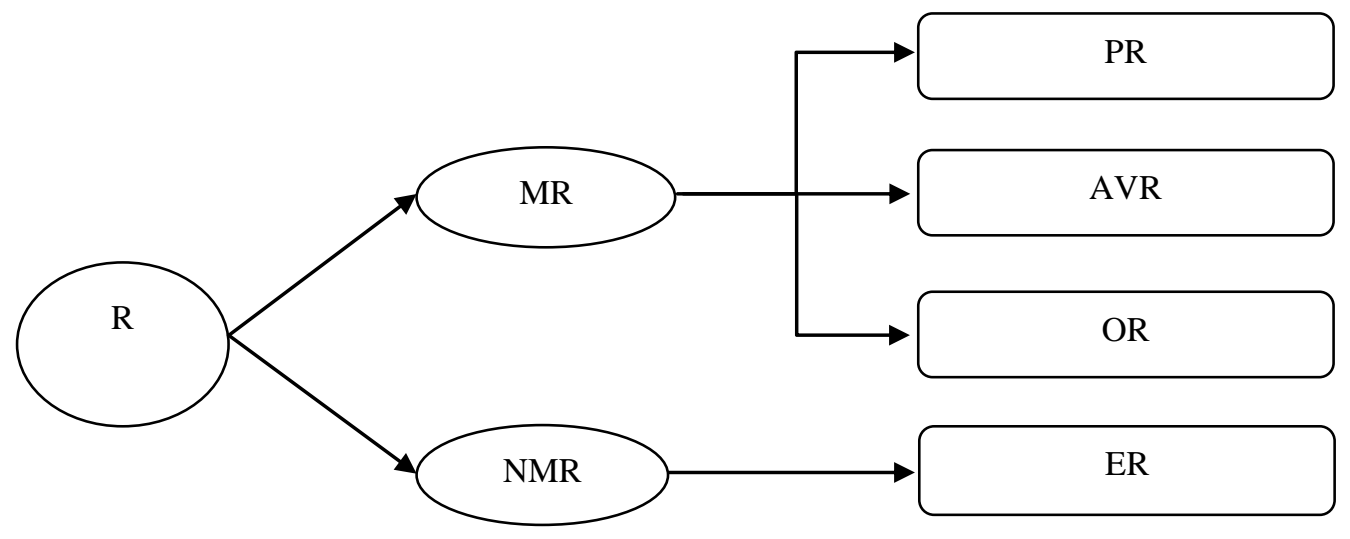

Figure 1. The relation between different types of the teachers' resources

Figure 1 shows the categorization of the system of resources of the teachers (coded, $\mathrm{K}$ ) as a combination of four categories: paper resources (coded, PR), object resource (coded, OR), audio-visual resource (coded, AVR) and the evoked resources (coded, ER). In summary, this section presented some elements of the theoretical framework adopted in the following research to identify the selected resources of physics teachers and the integrated ones. Gueudet and Trouche presented a frame to study the mobilized resources and the work of the teachers on these resources to build their teaching activities. Through the documentational approach this study interested in the characterization of different types of resources forming the system of resources of physics teachers.

\section{Method}

\section{Research Design}

This study follows a qualitative approach to explore the resources used by the Lebanese secondary physics teachers in their teaching in general and particularly for teaching Electricity for grade ten students. Moreover, it aimed to explore the objectives of use of resources and the factors affecting their selection and integration in the teaching-learning process.

\section{Participants}

This research was designed as a collective case study where four teachers were purposefully selected, from 101 Physics teachers attending the annual meeting to discuss the answer key of the official exams. The four teachers where given the pseudonyms Mark, Salam, Moustafa and Amir were selected for in-depth investigation. They had different profiles they all taught grade ten students and they integrated resources in their teaching. Table 1 shows a comparison between the different profiles and work environments of the selected participants. The four teachers had a Bachelor of Science (BS) in physics except Amir who has a BS in Electronics, while Salam and Moustafa had also a Teaching Diploma (TD) from the faculty of education. They all teach secondary classes in English or in French and have teaching experience ranging between 8 and 17 years. The four teachers worked in public or private schools of different level of setting and equipment. 
Table 1. Comparison between the selected teachers' profiles and school settings

\begin{tabular}{ccccc}
\hline & Mark & Salam & Moustafa & Amir \\
\hline University's Diplomas & BS & BS + TD & BS + TD & BS \\
\hline Major & Physics & Physics & Physics & Electronics \\
\hline Teaching Experience & 13 years & 8 years & 8 years & 17 years \\
\hline Language of Teaching & English & English & English & French \\
\hline School Type & Private & Public & Public & Public \\
\hline Level of Equipment & Acceptable & Poor & Poor & Poor
\end{tabular}

\section{Data Collection Tools}

The data collection tools were the interviews and the classroom observations. The interviews were two semistructured interviews, one general (GI) and the other specific (SI), that aimed to explore the system of resources mobilized by the teachers in their teaching in general and in teaching Electricity in particular. This system of resources claimed by teachers during the interviews about their teaching is called system of Stated Resources (SR). To enhance credibility, the interviews were video-taped and transcribed then the participants read the transcript by themselves to ensure that their ideas were well expressed. These two interviews (GI \& SI) were monitored before the classroom observations.

The classroom observations were all about the chapter of "generators and receivers" in the unit of Electricity. The number of observations varied between five and nine sessions according to the teacher progression. In addition to videotaped observations, the first researcher took notes for all observed details in the class. Thus, he is said to be the data-collection instrument (Johnson \& Christensen, 2008). Therefore, videos of the observed sessions allowed the partially reconstruction of the studied situation and allowed for viewing and reviewing of the video-taped sessions. Besides that, the videos provided access to verbal and non-verbal interactions between the different speakers in the classroom (teacher-student, student-student). Moreover, it allowed studying the resources implemented by teachers in class in order to present specific topic. These resources are called Integrated Resources (IR). Thus, the classroom observation formed an essential part in the educational research particularly to monitor the professional work of teachers in the classroom (Gueudet \& Trouche, 2010) and to explore teachers' system of integrated resources. All the observed sessions were videotaped by two cameras from two different angles to collect maximum data of verbal and non-verbal behavior of the teacher and of the students. During the classroom observations, notes and reflections were taken excessively in order to clarify more the global image of the teaching learning process. The recording devices give the opportunity for the researchers to replay as many times as they desire in order to validate the captured data and other researchers can also have the chance to watch and to listen and to discuss.

\section{Method of Data Analysis}

The interviews and classroom observations were analyzed in three steps: first the interviews and videos were transcribed. Second the discourse was segmented into meaningful analytical units, coded and categorized into themes. Finally, the types of the stated and the integrated resources (SR \& IR) were identified. To analyze the resources and their objectives of use, a grid of analysis was adopted from the work of Gueudet and Trouche, (2007) and Hammoud, (2012). This grid of analysis of resources (R) is mainly based on three categories related to: the type of the resources, the content presented in the resources and the didactical organization.

Regarding the type of resources (R), teachers may refer to many material resources (MR) and non-material resources (NMR). Material resources included three sub-categories: paper resources (documents, books, copybook...), object resources (lab tools, real life tools) and audio-visual resources (videos, CDs, software, images...). The non-material resources, also called Evoked resources (ER), were the examples about natural phenomena, features or any material situation related to the taught subject that teachers could use it in their professional work.

Concerning the second category about the physics content organization, the researchers detailed, from a physics point of view, the knowledge included in the content and the predictable learning difficulty related to it. In addition, the researchers tried to analyze, in terms of the content specification, the relevance of the choice of the teacher for a specific resource. 
The third category was about the didactical organization of the implemented resource of how and when the teacher integrated a specific resource to present specific content. In order to deduce the objective of usage of the resource, the researchers detailed the strategy by which the teacher organized the progression of knowledge in his teaching activity and the role of the used resource.

\section{Results and Discussion}

Concerning the resources used by the four teachers in their professional work, the analysis of data collected from the interviews, showed that they used many types of resources (OR, PR, AVR and ER) in their teaching. In the interviews, teachers specified the use of these resources (SR) according to the content (specific physics topics) they intended to teach and the objectives of their use. These objectives, stated by the four teachers, presented many elements of similarity in terms of pedagogical goals. Table 2 presents the main common objectives associated by the four teachers for the use of each type of resources. It shows that teachers referred to the real objects when they perform experiments about the taught subjects or when they introduce specific physics content. In addition, they also used OR to enhance learning and remove misconceptions. Due to the lack of materials and equipments in the school setting, teachers stated that they mobilized the other types of resources i.e. the visual and the evoked resources to compensate this lack.

On the other hand, the evoked resources (ER) were the most useful resources that the teachers mobilized in their teaching. This kind of resources was related to teachers' knowledge about the application of some physics principles in the practical life and about some phenomena or features related to the taught topics in their classroom. The audio-visual resources (AVR) were mainly used for illustrating some concepts and to show some phenomena. Concerning the paper resources (PR), all the teachers used the official textbook to prepare their course according to the curriculum objectives. Moreover, they relied on PR to find exercises of application and to solve problems about the topic.

Table 2. The objectives of usage associated to the stated resources (SR)

\begin{tabular}{|c|c|}
\hline Types of resources & Objectives of usage \\
\hline $\begin{array}{l}\text { Object resources } \\
(\mathrm{OR})\end{array}$ & $\begin{array}{ll}\text { 1. } & \text { Introduce content } \\
\text { 2. } & \text { Explain or clarify a law } \\
\text { 3. } & \text { Facilitate learning and } \\
& \text { remove misconceptions }\end{array}$ \\
\hline $\begin{array}{c}\text { Audio-Visual resources } \\
\text { (AVR) }\end{array}$ & $\begin{array}{ll}\text { 1. } & \text { Replace real objects } \\
\text { 2. } & \text { Show some phenomena } \\
\text { 3. } & \text { Illustrate physics principle }\end{array}$ \\
\hline $\begin{array}{c}\text { Paper resources } \\
(\mathrm{PR})\end{array}$ & $\begin{array}{l}\text { 1. Prepare course } \\
\text { 2. Find exercises and } \\
\text { problems }\end{array}$ \\
\hline $\begin{array}{l}\text { Evoked resources } \\
\text { (ER) }\end{array}$ & $\begin{array}{l}\text { 1. Replace real objects } \\
\text { 2. Relate physics to the real } \\
\text { life } \\
\text { 3. Introduce content } \\
\text { 4. Illustrate physics principle }\end{array}$ \\
\hline
\end{tabular}

One of the aims of this research was to study the specificity of teaching Electricity in grade ten in terms of the integrated resources and the objectives of their usage. The four teachers were observed in their classrooms during their explanation of the chapter of "generators and receivers". The explanation of the chapter done by each teacher showed that they all followed the same progression presented by the curriculum. This chapter about generators and receivers is divided according to the official textbook to three main parts: Electric generators and its characteristics, electric receivers and its characteristics, and some particular cases (generators in oppositions and blocked motor). The analysis of data collected from the classroom observations, showed that Mark referred to the real objects to perform experiment about the different parts in the chapter. He used the experimental activity to determine the characteristics of an electric generator and an electric receiver and to explain Ohm's law relative to them. He also referred to the evoked resources by giving examples from the real life about generators and receivers to illustrate the principle of conservation of energy responsible of how they function. The other three teachers (Salam, Moustafa, and Amir) referred mainly to the evoked resources and the audiovisual resources to explain the main ideas of the chapters. On the other hand, Salam used materials that he 
brought by himself to introduce electric generators, while, to determine the characteristics of generators and receivers, Salam and Moustafa referred to the virtual lab. Salam used different simulation software for the three different parts of the chapter. The software that Salam and Moustafa used was given to them from their colleagues and from the Faculty of Education when they were preparing their Teaching Diploma (TD). Thus, Salam's system of integrated resources was rich, as he has used real objects, evoked resources, three simulations software and the official book. Moustafa and Amir did not use any object resources (OR) during their explanation. Amir referred only to the evoked resources (ER) during his explanation where he tried to relate physics knowledge to their application in the real world by giving examples from students' real life. However, to solve exercises and problems the four teachers referred to the textbook (PR). Table 3 summarizes in terms of the main taught ideas the different types of the integrated resources (IR) used by the four teachers during the explanation of the chapter of generators and receivers.

Table 3. The objectives of usage associated to the integrated resources (IR)

\begin{tabular}{ccccc}
\hline Progression & Mark & Salam & Moustafa & Amir \\
\hline $\begin{array}{c}\text { To introduce Electric } \\
\text { generators }\end{array}$ & OR & OR & ER & ER \\
\hline $\begin{array}{c}\text { To introduce Electric } \\
\text { receivers }\end{array}$ & OR & ER & ER & ER \\
\hline $\begin{array}{c}\text { To show Ohm's law } \\
\text { related to generators }\end{array}$ & OR & AVR & AVR & ER \\
\hline $\begin{array}{c}\text { To show Ohm's law } \\
\text { related receivers }\end{array}$ & OR & AVR & ER & ER \\
\hline $\begin{array}{c}\text { To explain generators } \\
\text { in oppositions }\end{array}$ & ER & AVR & AVR & ER \\
\hline To solve exercises & PR & PR & PR & PR \\
\hline
\end{tabular}

Concerning the role of the experimental activity in their teaching, the four teachers stated that it formed the most important strategy for teaching and learning physics. According to their declarations, Mark, Salam and Moustafa appreciated the role of the experiment in teaching physics because it put theory into practice and students had the opportunity to construct their knowledge by themselves and enhance their understanding. Furthermore, they believed that experiments are irreplaceable, but due to lack of materials, they referred to the practical examples (ER) and to the virtual laboratory (AVR). However, Mark had the chance to perform laboratory experiments since he taught in a private school where the needed materials in Electricity were present in school laboratory. Otherwise, he would be obliged, like the other teachers, to find other resources to replace the object resources (OR). Salam and Moustafa taught in public schools, which were poor in equipment and laboratories, thus they used the virtual experimental activity and some of their own materials. Moreover, Salam found that the virtual lab is more efficient at the level of time saving, precision, clarity and management. In addition, Salam added that the audio-visual resources are more efficient when topics are not applicable in school's laboratory (e.g., radioactivity). These two teachers Salam and Moustafa were comparable from their profile in three main points: the diplomas, the teaching experience and the school setting. They had their teaching diploma at the same year from the faculty of education at the Lebanese University where they got the simulation software. They have been teaching for eight years and were observed in public schools where there was lack of materials and equipment. In spite of this, Salam developed his documentation and his system of resources as well as his teaching practice more than Moustafa did. As a result, the lack of materials in public schools did not encourage teachers to choose real experimentation as instructional strategy in the chapter of "Generators and Receivers". However, physics teachers ranked the experimental activity as the first in teaching strategies due to its importance in the teaching learning process. Therefore, school setting affected the teacher's choice of resources, i.e. those teaching in public school were obliged to look for a replacement to the object resources. Moreover, all the four teachers appreciated the role of the evoked resources to relate the world of theory to the real world in particular, during the teaching of the unit of Electricity thus, the choice of resources is content dependent.

On another side, Amir also worked in a public school which was unequipped, and he believed that physics is better taught through practical knowledge. He used to draw diagrams illustrating the principle of functioning of some applications of physics contents in the real life. These diagrams showed proliferation in physics applications in the domain of Electricity. This level of knowledge and of accuracy presented in his classroom was not present in any of the other teachers' classroom, which could be explained by his long teaching experience in comparison with the others as well as his major (BS in Electronics). Therefore, all of his teaching activities in the chapter of generators and receivers were based on the evoked resources (ER). Thus, teaching 
experience and major are of the factors that influence teacher's practice, in addition to teacher's preparation and his professional knowledge about teaching physics.

As conclusion, the main results and findings of this study can be summarized by the following points:

- Secondary physics teachers used different types of resources in their teaching in general where the evoked resources (ER) formed the main common type.

- Secondary physics teachers referred mainly to the experimental activity (real lab or virtual lab) using object resources (OR) or audio-visual resources (AVR) in teaching Electricity.

- Secondary physics teachers paid particular attention to the importance of performing real experiments to enhance learning and remove students' misconceptions.

- Virtual laboratory could be more efficient than the real experiment in teaching some physics topics as it is less time consuming, more accurate, better organized and more precise, particularly at microscopic level.

- Concerning the factors that affect the selection and the integration of resources, the choice of the resource to present a specific content depends on:

$>\quad$ The content itself and its particularity

$>$ The availability of materials and equipment

$>$ Time constraints

$>$ Teaching experience and diplomas

$>$ Teacher's professional knowledge

\section{Discussion of the Results}

The results of this study showed that during their teaching preparation/teaching practice, teachers had access to a variety of resources (OR, PR, AVR and ER). The availability of these resources in teacher' work environment (laboratories, library, computers, internet, technological tools...) enhanced the selection and the integration of such resources. This is consistent with Hammoud (2012) who found that teachers did not have a unique system of resources; they referred to different types of resources to elaborate their teaching activities. Nowadays, the access of physics teachers to the internet and the use of some audio-visual resources to present specific topics became easier with the development of technology.

During their explanation of Electric Generators, Salam and Moustafa were obliged to modify the used simulation software to differentiate between real and ideal generators. Thus, the integration of technology in education required proliferation in its use to adapt it to specific content. This is in line with Sabra, who showed that the development of the integration of technology in education required development in teacher's skills about its use (Sabra, 2011). According to Abd-El-Khalick (2005), the integration of technology in education required a development in the curricular goals and approaches. Nevertheless, Mounsef (2005) found that the integration of ICT is not emphasized in Lebanese science curriculum. Furthermore, the result showed that the visual resources of Salam and Moustafa were enriched by their collaborative work with other colleagues and from the Faculty of Education during their preparation for the TD (Teaching Diploma). They used during the explanation of the chapter of "Generators and receivers" the simulation software they brought from their colleagues. Therefore, the collective work developed their documentary work. This is consistent with Hammoud (2012), Sabra (2009) and Shaaban (2014) who showed that the collective work leads to an evolution of teacher's documentary work and their practices.

This study also showed that the physics teachers believed that the experimental activity in general and the real laboratory in particular were the best ways to teach physics in general and Electricity in particular. During interviews, Mark, Moustafa and Amir claimed that the experimental activity using real objects and tools is irreplaceable in the teaching/learning process. While Salam found that, the virtual laboratory is more efficient than the real one due to many reasons such as the time saving, the organization, the accuracy and microscopic scale of observation. Moreover, simulation software could be a solution for the lack of materials and laboratories, and for some topics such as astronomy and radioactivity. This is consistent with several previous studies like Bajpai and Kumar (2015) who found that the virtual laboratory in physics played an essential and significant role 
to develop students' science process skills. They found also that the virtual lab is useful when experiments involved hazardous chemicals or risky equipment. Other researchers (Redish et al., 1997; Svec \& Anderson, 1995; Zoubeir, 2000) revealed that computer simulation experiments are more effective for students' understanding than traditional experiments. In contrary, some researches revealed no difference in the effectiveness between real and virtual labs (Bayrak et al., 2007; Miller, 1986). The inconsistency between the results could be related to the specificity of the topic included, in particular when real experiment is inadequate, which limits the real experiment in developing some concepts (Yager et al., 1969).

Furthermore, this study revealed that many factors hindered the integration of resources in the teaching process. These factors were related mainly to the content itself, the school setting and the teacher's professional knowledge. Moreover, Mark and Salam claimed that there is no sufficient time to perform experiment and integrate resources in their teaching in a continuous way due to the condensed curriculum. This is in line with some researchers who found that one of the factors affecting the use of resources is their availability in teacher' work environment (Haney, Czerniak, \& Lumpe, 1996; Nargund-Joshi, Rogers, \& Akerson, 2011). Some other researchers revealed that the time constraint is one of the factors hindering the implementation of resources (Bodzin, Cates, \& Price, 2003; Keiser \& Lambdin, 1996).

\section{Conclusion}

This paper presents a study about the system of resources used by Lebanese secondary Physics Teachers during their teaching preparation/teaching practice in general and for Electricity in particular. It aimed to study the different types of used resources, their objectives and the factors that may affect their selection and their use. The analysis of data showed that, in order to elaborate and present their teaching activity, Secondary Physics Teachers referred to different types of resource (OR, VR, PR and ER) depending mainly on the availability of these resources in teachers' work environments (school setting and equipment) and the content to be taught. The school setting and its equipment had a direct influence on the type of selected resources and teaching activity.

Most of the resources were mobilized to compensate the lack of materials (OR) and to illustrate specific physics topics. Teachers believed that the experimentation is the most important instructional strategy to enhance students' understanding and to remove misconceptions in learning physics in general and Electricity in particular. Using virtual laboratory through VR could be more efficient at the level of time consuming, accuracy, management and teaching at the microscopic level (e.g., Radioactivity). In addition to the content itself and its particularity and the availability of materials, the time constraint and teacher's pedagogical knowledge affect the selection of resources of different types. Furthermore, the major (Electronics, pure Physics...), the diploma (BS, TD, Master...) and the years of experience affected the selection and the integration of resources in general and the evoked resources (ER) in particular.

\section{Recommendations and Implications}

Future studies/interventions could arise from the discussion of the results of this study. This study showed that the selection of resources is content dependent, thus other research could test this result by choosing Physics topics other than the Electricity to explore if the selection and the integration of resources is different. Furthermore, future researchers can investigate how teachers' professional knowledge affects the selection and the use of resources such as the technological and the pedagogical content knowledge.

The integration of resources in general and the ICT in particular required organizational support and change in the whole school culture (Zgheib, 2013) and re-examining curricular goals (Abd-El-Khalick, 2005). Therefore, physics curricula, their objectives, the approaches and the required skills should be revised by the curriculum designers and educators and by the educational websites developers to support teachers in efficiently integrating resources in their professional work.

\section{Acknowledgment}

The current study presents some limitation related to the small number of case studies, the specification of one subject and one topic in science curriculum and the time constraint that prevent analyzing deeply the quality of used resources. 


\section{References}

Abd-EL-Khalick, F. (2005). Instructional technology in secondary science teaching. In I. Osta (Ed.), Education and Information Technology in the Arab Countries: Issues and Trends (in Arabic) (pp. 329-355). Beirut: Lebanese Association for Educational Studies.

Adler, J. (2010). La conceptualisation des ressources. Apports pour la formation des professeurs de mathématiques. In G. Gueudet \& L. Trouche, Ressources vives le travail documentaire des professeurs en mathématiques (pp. 23-39). Rennes : Presses Universitaires de Rennes et INRP.

Artigue M., Gueudet G. (2008). Ressources en ligne et enseignement des mathématiques. Conférence à l'Université d'été de mathématiques, Saint-Flour.

Retrieved from: http://www3.acclermont.fr/pedago/maths/pages/UE2008/prog_UE_2008.htm

Bajpai, M., \& Kumar, A. (2015). Effect of virtual laboratory on students' conceptual achievement in physics. International Journal of Current Research, 7(2), 12808-12813.

Retrieved from: http://www.journalcra.com/sites/default/files/7619.pdf

Bayrak, B., Kanli, U. (2007). To compare the effects of computer based learning and the laboratory based learning on students' achievement regarding electric circuits. Turkish Online Journal of Educational Technology, 6 (2), p15.

Bodzin, A. M., Cates, W. M., \& Price, B. (2003). Formative evaluation of the exploring life curriculum: Year two implementation fidelity findings. Paper presented at the meeting of the National Association for Research in Science Teaching (NARST), Philadelphia, PA.

BouJaoude, S. \& Abd-El-Khalick, F. (2004).A decade of science education research in Lebanon (1992-2002): Trends and issues. In K. Mutua \&C.S. Sunal (Eds.), Research on Education in Africa, the Caribbean, and the Middle East (Vol. 1, pp. 203-241). Greenwich CT: Info Age Press.

BouJaoude, S. \& El Hage, F. (2009). Recherches en didactique des sciences au Liban (2002-2008): Tendances \& perspectives. [PowerPoint Slides]. Retrieved April, 2016, from: http://www.fsedu.usj.edu.lb/activites/carrefour08-09/fadihage-saoumab.pdf.

Eid, N. (2008). Integration of information and communication technology in the teaching of life and earth sciences: Advantages and limitations. Unpublished Master's thesis, Saint Joseph University, Beirut, Lebanon (in French).

Flick, L. \& Bell, R. (2000). Preparing tomorrow's science teachers to use technology: Guidelines for science educators. Contemporary Issues in Technology and Teacher Education, 1(1) 39-60.

Grangeat, M., \& Gray, P. (2007). Factors influencing teachers' professional competence development. Journal of Vocational Education \& Training, 59, 485-501.

Gueudet, G., Trouche, L. (2007) Vers de nouveaux systèmes documentaires pour les professeurs de mathématiques ? In I. Bloch \& F. Conne. Actes de la XIVe école d'été de didactique des mathématiques, Saint- Livrade.

Gueudet, G., \& Trouche, L. (2008). Du travail documentaire des enseignants : genèses, collectifs, communautés. Le cas des mathématiques. Education et Didactique, 2, 7-33.

Gueudet, G., \& Trouche, L. (2009). Towards new documentary systems for mathematics teachers? Educational Studies in Mathematics, 71, 199-218

Gueudet, G., \& Trouche, L. (2010). Des ressources aux documents, travail du professeur et genèses documentaires. In G. Gueudet, L. Trouche (dir.), Ressources vives. Le travail documentaire des professeurs en mathématiques (pp.57-74). Presses Universitaires de Rennes et INRP.

Hammoud, R. (2012). Le travail collectif des professeurs en chimie comme levier pour la mise en auvre de démarches d'investigation et le développement des connaissances professionnelles. Contribution au développement de l'approche documentaire $d u$ didactique. Thèse de doctorat (inédit), Université Claude Bernard Lyon 1, France et Université Libanaise, Liban.

Haney, J. J., Czerniak, C. M., \& Lumpe, A. T. (1996). Teacher beliefs and intentions regarding the implementation of science education reform strands. Journal of Research in Science Teaching, 33, 971-993.

Jacobsen, M. (2001). Building different bridges: Technology integration, engaged student learning, and new approaches to professional development (Report TM 032-583). Retrieved from:http://www.eric.ed.gov/ERICWebPortal/recordDetail?accno=ED453232

Johnson, B. \& Christensen, L. (2008). Educational research: Quantitative, qualitative and mixed approaches. Los Angeles, CA: Sage.

Jurdak, M., BouJaoude, S. \& Ghumrawi, N. (2007). Comparison of mathematization in microcomputer based laboratory (MBL) and verification-type laboratory (VTL) in physics. In P. Pitta-Pantazi \& G. Philippou (Eds.), Proceedings of the Fifth Congress of the European Society for Research in Mathematics Education (pp. 2110-2119). Larnaka, Cyprus: University of Cyprus. 
Keiser, J. M., \& Lambdin, D. V. (1996). The clock is ticking: Time constraint issue in mathematics teaching reform. Journal of Educational Research, 90(1), 23-30.

Miller, D. G. 1986. The Integration of Computer Simulation into The Community College General Biology Laboratory. Dissertation Abstract Int, 47:2106-A.

Mounsef, Y. (2005). ICT- based education in the Arab countries: Experience and lessons learnt. In I. Osta (Ed), Education and Information Technology in the Arab Countries: Issues and Trends (in Arabic) (pp. 179207). Beirut: Lebanese Association for Educational Studies.

Nargund-Joshi, V., Rogers, M. A. P., \& Akerson, V. L. (2011). Exploring Indian secondary teachers' orientations and practice for teaching science in an era of reform. Journal of Research in Science Teaching, 48(6), 624-647.

Rabardel, P. (1995), Les Hommes et les technologies : une approche cognitive des instruments contemporains. Armand Colin.

Redish, F. E., Jeffery S. M., and Steinberg R. N. 1997. On the Effectiveness of Active Engagement Microcomputer based laboratories. Department of Physics. University of Maryland College Park, MD20742 Reed

Sabra, H. (2011) and Trouche L. Contribution à l'étude du travail documentaire des enseignants de mathématiques : les incidents comme révélateurs des rapports entre documentations individuelle et communautaire. Thèse de Doctorat. Université Lyon1.

Shaaban, E., (2014). The Interactions between Resources, Particularly Digital Resources, and Biology Teachers' Conceptions during their Documentary Work: Case of Teaching Genetic Determinism at Secondary Level, Lebanon. Doctoral thesis, Lebanese University, Lebanon.

Shihab, M. (2000). The effect of using web-based hypermedia versus text-based instruction on students' achievement in the classification of animals. Unpublished master's thesis, American University of Beirut, Beirut, Lebanon.

Shulman, L. S. (1987). Knowledge and teaching: Foundations of the new reform. Harvard Educational Review, 57(1), 1-22.

Spring, J. (2011). The Politics of American Education. Routledge Press.

Svec, M., T and Anderson, H., 1995. Effect of Microcomputer-Based Laboratory on Students Graphing Interpretation Skills and Conceptual Understanding of Motion. Dissertation Abstracts Int, 2338-A.

Vergnaud G. (1996), Au fond de l'apprentissage, la conceptualisation. In R. Noirfalise \& M.-J. Perrin (dir.), Ecole d'été de didactique des mathématiques (pp. 174-185). Clermond-Ferrand : IREM.

Webb, M. E. (2008). Impact of IT on Science Education. In J. Voogt \& G. Knezek (Eds.). International Handbook of Information Technology in Primary and Secondary Education (pp. 133-148). UK: King's College London.

Yager, R. E., Engen, H. B, \& Snider, B. C. F. (1969), "Effect of the Laboratory and Demonstartion Methods upon the Outcomes of Instruction in Secondary Biology". Journal of Research in Science Teaching, 6, pp. 76-86.

Zgheib R. S. (2013). Organizational support of technology integration in one school in Lebanon (Doctoral dissertation). Retrieved from ProQuest Dissertations and Theses database. (UMI No. 3596298)

Zoubeir, W. F. (2000). Grafting computer projected simulations and interactive engagement methods within a traditional classroom setting: the influence on secondary level students' understanding of Newtonian mechanics and on attitudes towards physics (Doctoral dissertation). Retrieved from ProQuest Dissertations and Theses database. (UMI No. 9988370)

\begin{tabular}{lc}
\hline & Author Information \\
\hline Bassel Chazbeck & Zalpha Ayoubi \\
Lebanese University, Faculty of Education & Lebanese University, Faculty of Education \\
Beirut, Lebanon & Beirut, Lebanon \\
Contact e-mail: basselchazbeck@live.com & \\
\hline
\end{tabular}

